DOI https://doi.org/10.18551/rjoas.2018-08.46

\title{
BIOECONOMIC ANALYSIS OF HAIRTAIL FISH RESOURCES (TRICHIURUS SP.) IN THE WATERS OF KEBUMEN REGENCY
}

\author{
Widiyanto Agus, Wijayanto Dian*, Saputra Suradi Wijaya \\ Coastal Resources Management Program, Department of Fisheries, \\ Faculty of Fisheries and Marine Science, Diponegoro University, Indonesia \\ ${ }^{*}$ E-mail: widiyantoa8@gmail.com
}

\begin{abstract}
Hairtail Fish (Trichiurus sp.) is one of the potential export commodities in the international market. The worldwide export value of hairtail fish had increased by $128 \%$ within the period of 2011-2015. In 2015, it increased by US $\$ 15.5$ million from the previous year. Great market opportunities to meet market needs lead to increasing fishery resource utilization. Uncontrolled resource exploitation threatens the sustainability of fishery resources. Solutions that can be done to overcome uncontrolled resource exploitation are to lower the effort rate and increase the fishing productivity. Fishing productivity can be improved with the development and innovation of fishing gears and accurate information on hairtail fishing and spawning seasons and zones.
\end{abstract}

\section{KEY WORDS}

Hairtail fish, waters, international market, utilization rate.

The waters of Kebumen Regency are included in the Fishing Management Area (WPP) 573. According to Decree of the Ministry of Marine Affairs and Fisheries Number 47 of 2016, some fishery resources in WPP 573 are over-exploited, such as reef fish, penaeid shrimp, crab, and squid with utilization rates of $136 \%, 136 \%, 105 \%$, and $140 \%$ respectively. Meanwhile, the other resources are fully-exploited, such as small pelagic fish, big pelagic fish, demersal fish, lobster, and swimming crab (Portunus pelagicus) with utilization rates of $91 \%, 73 \%, 96 \%, 54 \%$, and $64 \%$.

There are 10 dominant demersal fish species caught in WPP 573, covering hairtail $(23.2 \%)$, red snapper $(16 \%)$, ornate ponyfish $(12.8 \%)$, seabass/ barramundi $(9.9 \%)$, pompano $(9.8 \%)$, threadfin bream $(9.3 \%)$, croaker $(6.3 \%)$, black pomfret $(4.9 \%)$, sea catfish (4.8\%), goatfish (3.3\%) (Fisheries Research Center, 2014). Of the ten fish species, hairtail fish is the most dominant fish caught by $23.2 \%$.

The international market opportunities for hairtail fish resources are large enough. The value of Indonesian hairtail fish export to the world experienced an increase of $128 \%$ during 2011 - 2015. From 2014 to 2015, the hairtail fish export value increased from US \$12 million to US $\$ 27.5$ million. The main destinations of Indonesian hairtail fish export are Vietnam, China, and Korea (the Ministry of Trade, 2016)

Several studies on the utilization of hairtail fish resources in southern Java Island (WPP 573) have shown a great opportunity for the improvement of hairtail fish utilization. Dian Putri Utami et al. (2012) stated that the fishing effort of hairtail fish in Parigi Waters, Ciamis Regency can still be increased up to 13,312 trips per year.

The magnitude of the international market potential leads to increased fishing efforts. On the other side, increased uncontrolled fishing efforts are feared to threaten the sustainability of hairtail fish resources. This research aimed to analyze the CPUE, MSY, MEY, OAE and utilization rate of hairtail fish resources in the Waters of Kebumen Regency. Actual information on the utilization status of hairtail fish resources in the Waters of Kebumen Regency is expected to be used as inputs in determining sustainable hairtail fishing management strategies in Kebumen Regency 


\section{MATERIALS AND METHODS OF RESEARCH}

The materials referred to in this research covered all fishing efforts to bring the hairtail fish catch landedin all Fish Auction Place (TPI) in Kebumen Regency during 2008-2017. The fishing gears used by fishermen in Kebumen Regency to catch hairtail fish were Drift Gillnet, Fixed Gillnet, Hook and line, and Beach Net. The type of boats used by these fishermen was gross tonnage (GT) with a temple motor driveof 15 horsepower (HP). The location of this research was the waters of Kebumen Regency.

This research was conducted using a descriptivemethod with a case study. Descriptive method is a method of studying the status of a group of men, objects, conditions, systems of thought or a class of thought in the present with the aim to obtain a systematic, factual, and accurate description and relationship between the investigated phenomena (Nazir, 2009).

Data used in this research consisted of primary and secondary data. The primary data were obtained directly from the community or fishermen through a questionnaire method reinforced and supported by observations and interviews. Meanwhile, the secondary data were collected from the literature of related institutions, in this case referring to the Office of Marine Affairs and Fisheries of Kebumen Regency and the Office of Marine Affairs and Fisheries of Central Java Province.

In this research, the data analysis was conducted in the following steps:

Calculating Catch Per Unit Effort (CPUE). According to Nojja et al (2014), the value of CPUE is calculated to determine the abundance and utilization rate of fishery resources in certain areas. The hairtail fish CPUE of each fishing gear is calculated using the following formula:

$$
\text { CPUE }_{\mathrm{t}}=\frac{\text { Catch }_{t}}{\text { Effort }_{\mathrm{t}}}
$$

Where: CPUE $E_{\mathrm{t}}$ Catch Per Unit Effort in yeart $(\mathrm{kg} /$ trip); Catch: Production in year $t(\mathrm{~kg})$; Effort $t_{\mathrm{t}}$. Fishing Effort in year $t$ (trip).

Calculating Fishing Power Index (FPI). The highest value of CPUE is the standard CPUE. Each fishing gear has different capabilities in catching hairtail fish, so it needs to be standardized. Standardization of fishing gears will result in the value of Fishing Power Index (FPI). The fishing gear with the highest FPI value can be used as the standard or reference. In general, the fishing gear with the highest CPUE value has FPI value of 1 . The FPI value of other fishing gears can be calculated by dividing the CPUE value of the fishing gear with the standard CPUE of the fishing gear. The formula mathematically is presented as follows:

$$
\begin{gathered}
\text { CPUES }=\frac{C s}{E s} \\
\text { FPIs }=\frac{\text { CPUEs }}{\text { CPUES }} \\
\text { CPUE } i=\frac{C i}{E i} \\
F P I i=\frac{\text { CPUE } i}{\text { CPUES }}
\end{gathered}
$$

Where:

CPUEs: Catch Per Unit Effort of Standard Fishing Gear;

CPUEi: Catch Per Unit Effort of Fishing Gear Type I;

Cs: Total Catch of Standard Fishing Gear;

Ci: Total Catch of Standard Fishing Gear Type I;

Es: Total Effort of Standard Fishing Gear;

Ei: Total Effort of Fishing Gear Type I; 
FPIs: Fishing Power Index of Standard Fishing Gear;

FPli: Fishing Power Index of Fishing Gear Type i.

Calculating MSY, MEY, and OAE. Hairtail fish potential can be predicted by analyzing the catch and fishing effort. According to Spare and Venema (1999), one of the methods that can be used to predict the potential of this resource is Schaefer's production surplus model. The Gordon-Schaefer model-based bioeconomic analysis was developed by Schaefer using the logistic growth function developed by Gordon. There are three conditions of equilibrium in the Gordon-Schaefer model, covering MSY, MEY, and OAE (Dian Wijayanto, 2008). The detailed formula is presented in the following table:

Table 1 - Gordon-Schaefer Equilibrium Formula

\begin{tabular}{|c|c|c|c|}
\hline & MSY & MEY & OAE \\
\hline $\begin{array}{l}\text { Catch (C) } \\
\text { Effort (E) } \\
\text { Total Revenue (TR) } \\
\text { Total Cost (TC) } \\
\text { Profit }\end{array}$ & $\begin{array}{l}a^{2} / 4 b \\
a / 2 b \\
C_{M S Y^{*} p} \\
c^{\star} E_{M S Y} \\
T_{M S Y}-T_{M S Y} \\
\end{array}$ & $\begin{array}{l}a E_{M E Y}-b\left(E_{M E Y}\right)^{2} \\
(p a-c) /(2 p b) \\
C_{M E{ }^{*}} p \\
c^{*} C_{M E Y} \\
T_{M E Y}-T_{M E Y}\end{array}$ & $\begin{array}{l}\mathrm{aE}_{\mathrm{OAE}}-\mathrm{b}\left(\mathrm{E}_{\mathrm{OAE}}\right)^{2} \\
(\mathrm{pa}-\mathrm{c}) /(\mathrm{pb}) \\
\mathrm{C}_{\mathrm{OAE}}{ }^{*} \mathrm{p} \\
\mathrm{C}^{*} \mathrm{C}_{\mathrm{OAE}} \\
\mathrm{TR}_{\mathrm{OAE}}-\mathrm{TC}_{\mathrm{OAE}}\end{array}$ \\
\hline
\end{tabular}

Source: Wijayanto, 2008.

Utilization Rate. Utilization rate is used to determine the utilization status of resources. The formula of utilization rate is as follows:

$$
T P_{C}=\frac{C_{i}}{C_{M S Y}} \times 100 \%
$$

Where:

$\mathrm{TP}_{\mathrm{c}}=$ Utilization Rate (\%);

$\mathrm{C}_{\mathrm{i}}=$ Catch in year $i(\mathrm{~kg})$;

$\mathrm{C}_{\mathrm{MSY}}=$ Sustainable Maximum Catch $(\mathrm{kg})$.

Meanwhile, the Effort Rate is determined using the formula as follows:

$$
T P_{E}=\frac{E_{i}}{E_{M S Y}} \times 100 \%
$$

Where:

$\mathrm{TP}_{\mathrm{E}}=$ Effort Rate $(\%)$

$\mathrm{E}_{\mathrm{i}}=$ Effort in year $i(\mathrm{~kg})$;

$E_{M S Y}=$ Sustainable Maximum Effort $(\mathrm{kg})$.

\section{RESULTS AND DISCUSSION}

The highest production of hairtail fish was 569.1 tons in 2012 while the lowest production of hairtail fish was 125.7 tons in 2010. As seen in Table 2 below, the hairtail fish production was dominantly caught using Drift Gillnet.

As presented in Table 2, the average production of hairtail fish per year during 2008 2017 was 308.04 tons. Of the total average production per year, 266.62 tons of the hairtail fish production was caught using Drift Gilnett. Moreover, the average production of hairtail fish caught using Beach net amounted to 21.65 tons per year while that caught using Fixed Gillnet (Set Net) was 13.16 tons per year. The rest 6.61 tons (per year) were caught using Hook and line. Overall, the production of hairtail fish in Kebumen Regency Waters highly fluctuated. The highest production was 569.1 tons in 2012 and the lowest production amounted to 125.7 tons in 2010 . 
Table 2 - Production of Hairtail Fish in Kebumen Regency Waters During 2008- 2017

\begin{tabular}{|c|c|c|c|c|c|c|}
\hline \multirow[b]{2}{*}{ No } & \multirow[b]{2}{*}{ Year } & \multicolumn{4}{|c|}{ Production (ton) } & \multirow[b]{2}{*}{$\begin{array}{l}\text { Amount } \\
\text { (ton) }\end{array}$} \\
\hline & & Drift Gillnet & $\begin{array}{l}\text { Fixed Gillnet/ Set } \\
\text { Net }\end{array}$ & $\begin{array}{l}\text { Hook and } \\
\text { line }\end{array}$ & Beach-Net & \\
\hline 1 & 2008 & 356.1 & 60.1 & & & 416.2 \\
\hline 2 & 2009 & 146.9 & 8.2 & & 112.1 & 267.2 \\
\hline 3 & 2010 & 54.5 & 23.7 & & 47.5 & 125.7 \\
\hline 4 & 2011 & 165.5 & 3.2 & 4.2 & 38.2 & 211.1 \\
\hline 5 & 2012 & 535.9 & 10.3 & 4.2 & 18.7 & 569.1 \\
\hline 6 & 2013 & 305.4 & 5.4 & 34.6 & & 345.4 \\
\hline 7 & 2014 & 298.1 & 7.3 & 15.2 & & 320.6 \\
\hline 8 & 2015 & 425.3 & 10.6 & 7.9 & & 443.8 \\
\hline 9 & 2016 & 193.9 & 1.4 & & & 195.3 \\
\hline 10 & 2017 & 184.6 & 1.4 & & & 186.0 \\
\hline \multicolumn{2}{|c|}{$\begin{array}{l}\text { Total } \\
\text { Average }\end{array}$} & $\begin{array}{l}2,666.2 \\
266.62\end{array}$ & $\begin{array}{l}131.6 \\
13.16\end{array}$ & $\begin{array}{l}66.1 \\
6.61\end{array}$ & $\begin{array}{l}216.5 \\
21.65\end{array}$ & $\begin{array}{l}3,080.4 \\
308.04\end{array}$ \\
\hline
\end{tabular}

Source: Research (2018).

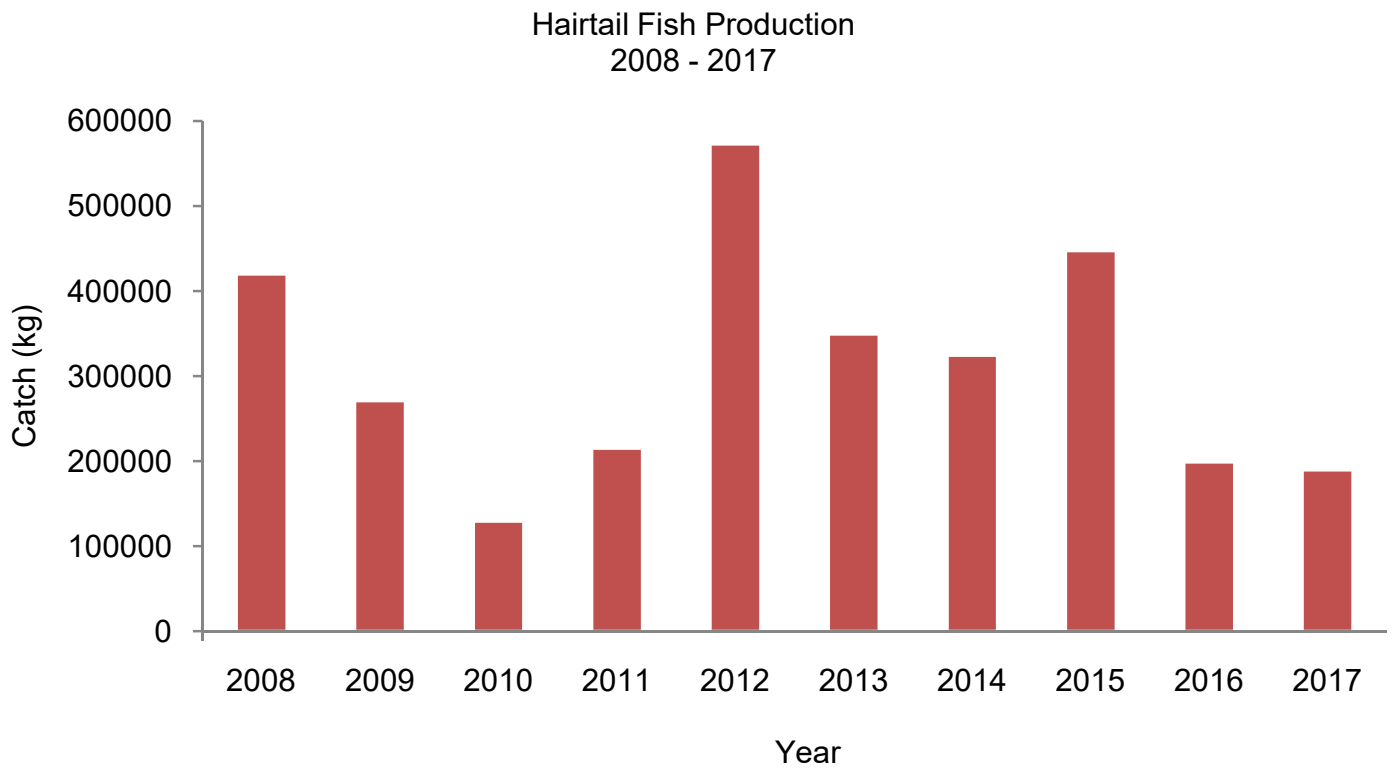

Source: Research (2018)

Figure 1 - Histogram of Hairtail Fish Production in Kebumen Regency Waters Within the Period of 2008-2017

CPUE (Catch per Unit Effort). CPUE can be used to determine the abundance and utilization rate of a fishery resource (Rahmawati et al., 2013). Based on observations during this research, there were four fishing gears used to catch hairtail fish, namely Drift Gillnet, Fixed Gillnet (Set Net), Beach Net, and Hook and line. During 2008 - 2017, not all the fishing gears were applied throughout the years. In 2008, 2016, and 2017, the production of hairtail fish came from the application of drift gillnet and fixed gillnet. In 2009 and 2010, three fishing gears were applied to catch hairtail fish, covering drift gillnet, fixed gillnet, and beach net. As for the production of hairtail fish in 2011 and 2012, it was obtained with the use of the four fishing gears. Meanwhile, in 2013, 2014 and 2015, the production of hairtail fish was yielded from the application of drift gillnet, fixed gillnet (set net), and hook and line. The fishing gears that were always used for catching hairtail fish were drift gillnet and fixed gillnet. Table 3 shows that the production, number of trips, CPUE, FPI and Standard Effort of Hairtail Fish Catching in Kebumen Regency during 2008 - 2017. 
Table 3 - Production, Trip, CPUE, FPI, and Utilization Effort of Hairtail Fish in Kebumen Regency Waters during 2008-2017

\begin{tabular}{|c|c|c|c|c|c|c|}
\hline Year & Fishing Gear Type & Number of Trips & Production (kg) & CPUE (kg/Trip) & $\mathrm{FPI}$ & Standard Effort (Trip) \\
\hline 2008 & $\begin{array}{c}\text { Drift Gillnet } \\
\text { Fixed Gillnet } \\
\text { Total }\end{array}$ & $\begin{array}{l}36,476 \\
29,494 \\
65,970\end{array}$ & $\begin{array}{c}356,124 \\
60,076 \\
416,200 \\
\end{array}$ & $\begin{array}{l}9.76 \\
2.04\end{array}$ & $\begin{array}{l}1.0000 \\
0.2086\end{array}$ & $\begin{array}{c}36,476 \\
6,153 \\
42,629\end{array}$ \\
\hline & Drift Gillnet & 2,461 & 146,900 & 59.69 & 1.0000 & 2,461 \\
\hline 2009 & $\begin{array}{c}\text { Fixed Gillnet } \\
\text { Beach net } \\
\text { Total }\end{array}$ & $\begin{array}{l}1,326 \\
2,550 \\
6,337\end{array}$ & $\begin{array}{c}8,200 \\
112,100 \\
267,200\end{array}$ & $\begin{array}{c}6.18 \\
43.96\end{array}$ & 0.1036 & $\begin{array}{c}137 \\
1,878 \\
4,476 \\
\end{array}$ \\
\hline 2010 & $\begin{array}{l}\text { Drift Gillnet } \\
\text { Fixed Gillnet } \\
\text { Beach net } \\
\text { Total }\end{array}$ & $\begin{array}{c}9,875 \\
7,642 \\
9,957 \\
27,474\end{array}$ & $\begin{array}{c}54,500 \\
23,700 \\
47,500 \\
125,700\end{array}$ & $\begin{array}{l}5.52 \\
3.10 \\
4.77\end{array}$ & $\begin{array}{l}1.0000 \\
0.5619 \\
0.8644\end{array}$ & $\begin{array}{c}9,875 \\
4,294 \\
8,607 \\
22,776\end{array}$ \\
\hline 2011 & $\begin{array}{l}\text { Drift Gillnet } \\
\text { Fixed Gillnet } \\
\text { Hook and line } \\
\text { Beach net } \\
\text { Total }\end{array}$ & $\begin{array}{l}2,461 \\
1,326 \\
1,262 \\
2,550 \\
7,599 \\
\end{array}$ & $\begin{array}{c}165,500 \\
3,210 \\
4,200 \\
38,200 \\
211,110 \\
\end{array}$ & $\begin{array}{c}67.25 \\
2.42 \\
3.33 \\
14.98\end{array}$ & $\begin{array}{l}1.0000 \\
0.0360 \\
0.0495 \\
0.2228\end{array}$ & $\begin{array}{c}2,461 \\
48 \\
62 \\
568 \\
3,139 \\
\end{array}$ \\
\hline 2012 & $\begin{array}{l}\text { Drift Gillnet } \\
\text { Fixed Gillnet } \\
\text { Hook and line } \\
\text { Beach net } \\
\text { Total }\end{array}$ & $\begin{array}{c}9,875 \\
7,642 \\
4,222 \\
9,957 \\
31,696\end{array}$ & $\begin{array}{c}535,900 \\
10,321 \\
4,200 \\
18,700 \\
569,121\end{array}$ & $\begin{array}{c}54.27 \\
1.35 \\
0.99 \\
1.88\end{array}$ & $\begin{array}{l}1.0000 \\
0.0249 \\
0.0183 \\
0.0346\end{array}$ & $\begin{array}{c}9,875 \\
190 \\
77 \\
345 \\
10,487\end{array}$ \\
\hline & $\begin{array}{l}\text { Drift Gillnet } \\
\text { Fixed Gillnet }\end{array}$ & $\begin{array}{c}50,863 \\
3,542\end{array}$ & $\begin{array}{c}305,400 \\
5,400\end{array}$ & $\begin{array}{l}6.00 \\
1.52\end{array}$ & $\begin{array}{l}0.5997 \\
0.1523\end{array}$ & $\begin{array}{c}30,505 \\
539\end{array}$ \\
\hline 2013 & $\begin{array}{c}\text { Hook and line } \\
\text { Total }\end{array}$ & $\begin{array}{c}3,456 \\
57,861\end{array}$ & $\begin{array}{c}34,600 \\
345,400\end{array}$ & 10.01 & 1.0000 & $\begin{array}{c}3,456 \\
34,500\end{array}$ \\
\hline 2014 & $\begin{array}{c}\text { Drift Gillnet } \\
\text { Fixed Gillnet } \\
\text { Hook and line } \\
\text { Total }\end{array}$ & $\begin{array}{c}46,860 \\
6,138 \\
611 \\
53,609\end{array}$ & $\begin{array}{c}298,100 \\
7,310 \\
15,200 \\
320,610\end{array}$ & $\begin{array}{c}6.36 \\
1.19 \\
24.88\end{array}$ & $\begin{array}{l}0.2557 \\
0.0479 \\
1.0000\end{array}$ & $\begin{array}{c}11,983 \\
294 \\
611 \\
12,888\end{array}$ \\
\hline 2015 & $\begin{array}{c}\text { Drift Gillnet } \\
\text { Fixed Gillnet } \\
\text { Hook and line } \\
\text { Total }\end{array}$ & $\begin{array}{c}37,240 \\
4,552 \\
1,549 \\
43,341\end{array}$ & $\begin{array}{c}425,342 \\
10,564 \\
7,910 \\
443,817\end{array}$ & $\begin{array}{l}11.42 \\
2.32 \\
5.11\end{array}$ & $\begin{array}{l}1.0000 \\
0.2032 \\
0.4471\end{array}$ & $\begin{array}{c}37,240 \\
925 \\
693 \\
38,857\end{array}$ \\
\hline 2016 & $\begin{array}{c}\text { Drift Gillnet } \\
\text { Fixed Gillnet } \\
\text { Total }\end{array}$ & $\begin{array}{c}13,745 \\
2,013 \\
15,758\end{array}$ & $\begin{array}{c}193,931 \\
1,421 \\
195,352\end{array}$ & $\begin{array}{c}14.11 \\
0.71\end{array}$ & $\begin{array}{l}1.0000 \\
0.0500\end{array}$ & $\begin{array}{c}13,745 \\
101 \\
13,846\end{array}$ \\
\hline 2017 & $\begin{array}{c}\text { Drift Gillnet } \\
\text { Fixed Gillnet } \\
\text { Total }\end{array}$ & $\begin{array}{c}39,721 \\
1,005 \\
40,726 \\
\end{array}$ & $\begin{array}{c}184,567 \\
1,421 \\
185,988\end{array}$ & $\begin{array}{l}4.65 \\
1.41\end{array}$ & $\begin{array}{l}1.0000 \\
0.3043\end{array}$ & $\begin{array}{c}39,721 \\
306 \\
40,027 \\
\end{array}$ \\
\hline
\end{tabular}

Source: Research (2018).

The number of trips from 2008 to 2017 very fluctuated. The smallest number of trips was 6,337 trips in 2009 while the largest number of trips was 65,970 trips in 2008. After standardization, the smallest number of standard trips was 3,139 trips in 2011 and the largest one was 42,629 trips in 2008. The lowest value of standard CPUE reached $4.65 \mathrm{~kg} /$ trip in 2017 and the highest value was $67.25 \mathrm{~kg} /$ trip in 2011.

Various studies have shown a negative correlation between CPUE and Effort. Patria, et al. (2014) stated that there is a negative correlation between the CPUE and Effort of shrimp catching in Cilacap Regency. This indicates that the higher effort of shrimp catching will decrease the CPUE value.

Table 4 - Correlation between Effort and CPUE

\begin{tabular}{l|l|l|l}
\hline Year & Total Production $(\mathrm{kg})$ & Standard Effort (trip) & Standard CPUE (kg/trip) \\
\hline 2008 & 416.2 & 42,629 & 9.76 \\
2009 & 267.2 & 4,476 & 59.69 \\
2010 & 125.7 & 22,776 & 5.52 \\
2011 & 211.1 & 3,139 & 67.25 \\
2012 & 569.1 & 10,487 & 54.27 \\
2013 & 345.4 & 34,500 & 10.01 \\
2014 & 320.6 & 12,888 & 24.88 \\
2015 & 443.8 & 38,857 & 11.42 \\
2016 & 195.3 & 13,846 & 14.11 \\
2017 & 186.0 & 40,027 & 4.65 \\
\hline
\end{tabular}

Source: Research (2018). 
Correlation between CPUE and Effort. Figure 2 below shows that the correlation between the CPUE and Effort was negative. It means that every increase in the fishing effort would decrease the catch per unit effort (CPUE). Based on the graph of the correlation between the CPUE and Effort of hairtail fish in Kebumen Regency Waters during 2008 2017, the linear equation obtained was $y=55.15-0.001 x$ with $R^{2}=0.666$, meaning that the intercept value (a) was 55.15 and the slope value (b) was 0.001 . This equation shows that:

- Any addition of 1 trip of Effort would cause the CPUE value to decrease by $0.001 \mathrm{~kg} /$ trip and any reduction of 1 trip of Effort would increase the CPUE value by $0.001 \mathrm{~kg} /$ trip;

- The determination coefficient $\left(\mathrm{R}^{2}\right)$ of 0.666 or $66.6 \%$ indicates that the $66.6 \%$ of the CPUE value was influenced by the Effort value while the rest $33.4 \%$ was influenced by other factors;

- The correlation coefficient $(R)$ of 0.82 indicates a close correlation between the CPUE and Effort.

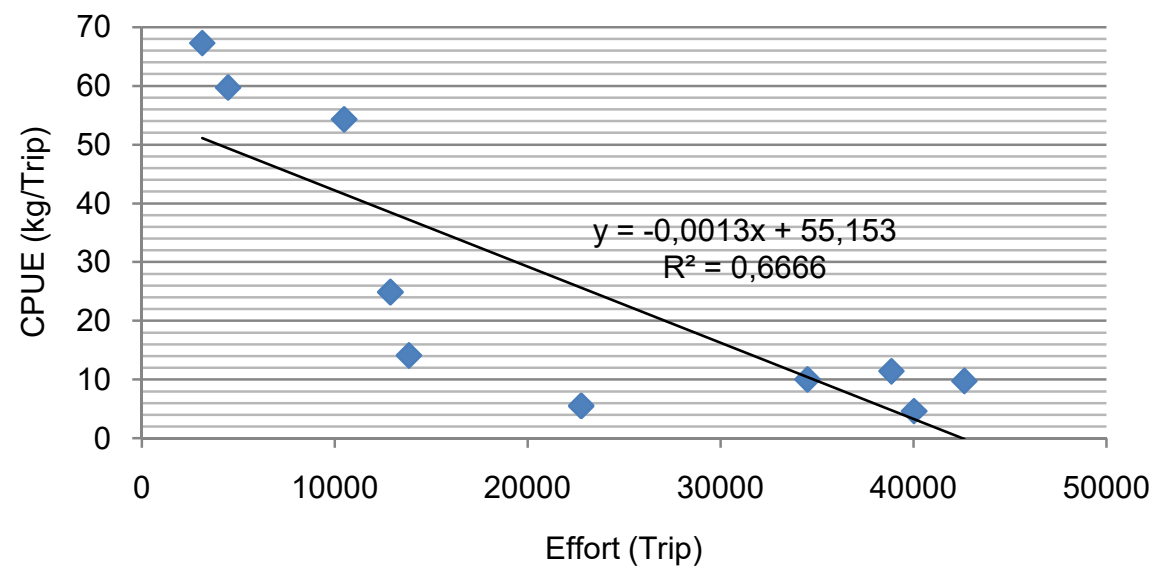

Source: Research (2018)

Figure 2 - Correlation Between CPUE and Effort of Hairtail Fish Within the Period of 2008-2017

MSY, MEY, and OAE. MSY is a reference for fishery resources management in an area that is still likely to be improved.By knowing MSY, the utilization rate of fishery resources will be maintained so that the resource stock will always be available at a safe level. According to Widodo and Suadi (2006), MSY is the highest or maximum catch that can be yielded year by year by a fishery resource.

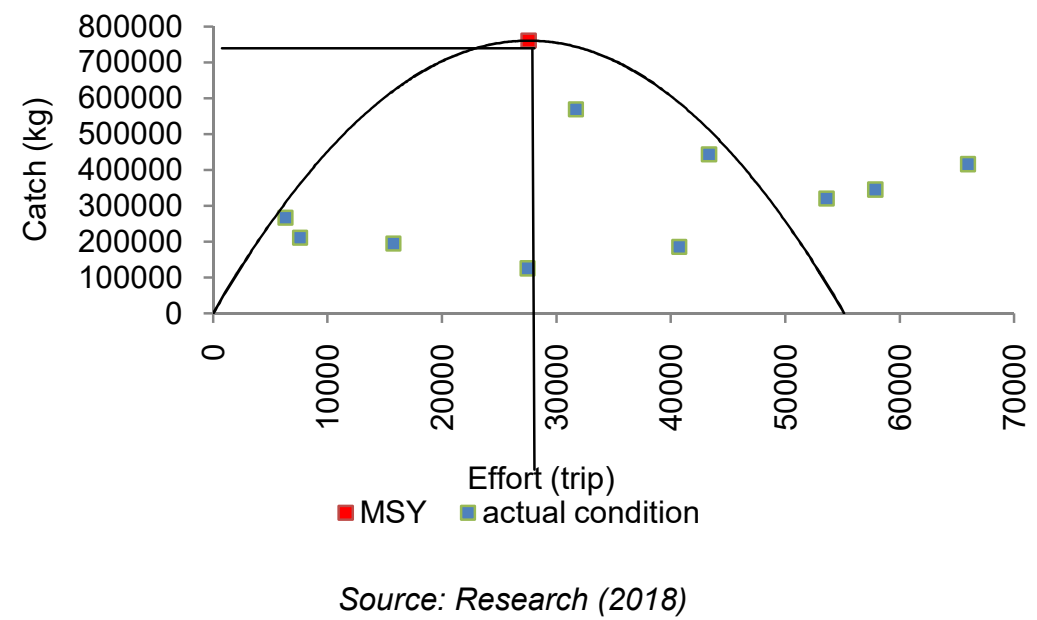

Figure 3 - MSY Curve of Hairtail Fishin Kebumen Regency Waters Within the Period of 2008-2017 
Based on the Schaefer model, the optimum effort $\left(E_{M S Y}\right)$ of hairtail fish resources in Kebumen Regency Waters was 27,575 trips/ year. Meanwhile, the sustainable or maximum catch $\left(\mathrm{C}_{\mathrm{MSY}}\right)$ was $760,380 \mathrm{~kg} /$ year. Viewed from the resulted sustainable catch value, it can be said that the actual catches of hairtail fish in Kebumen Regency Waters within the period of 2008 - 2017 have not reached the maximum catch $\left(\mathrm{C}_{\mathrm{MSY}}\right)$ but the efforts made have exceeded the maximum effort ( $\left.\mathrm{E}_{\mathrm{MSY}}\right)$.

Table 5 - Calculation Results of MSY, MEY, andOAE of Hairtail Fish in Kebumen Regency Waters within the Period $2008-2017$

\begin{tabular}{|c|c|c|c|}
\hline 12 & MSY & MEY & OAE \\
\hline Catch (C) & $760.380 \mathrm{~kg} / \mathrm{year}$ & $648.311 \mathrm{~kg} / \mathrm{year}$ & $719.388 \mathrm{~kg} /$ year \\
\hline Effort (E) & 27.575 trip/year & 16.988 trip/year & 33.977 trip/year \\
\hline Total Revenue (TR) & IDR 19.304.543.308 & Rp. 16.459.337.395 & Rp. 18.263.845.552 \\
\hline Total Cost (TC) & IDR 14.822.334.600 & Rp. 9.131.922.776 & Rp. 182.63.845.552 \\
\hline Profit $(\pi)$ & IDR 4.482.208.708 & Rp. 7.327.414.620 & Rp. 0 \\
\hline
\end{tabular}

Source: Research Results (2018).

Table 3 shows that the use of Drift Gillnet resulted in the highest average CPUE value. Therefore, this fishing gear was further analyzed for its economic profit. After determining the average economic profit, it was obtained that the price of hairtail fish was IDR 25,388 per kg and the price per trip was IDR 537,528.00. The economic profit under MSY condition was IDR 4,482,208,708.00. Meanwhile, under MEY condition, it was obtained that the maximum catch $\left(\mathrm{C}_{\mathrm{MEY}}\right)$ was $648,311 \mathrm{~kg} /$ year with the effort $\left(\mathrm{E}_{\mathrm{MEY}}\right)$ of 16,988 trips/ year, resulting in the economic profit of IDR 7,327,411,620.00. Furthermore, under OAE condition, the maximum catch $\left(C_{\text {OAE }}\right)$ was $719,388 \mathrm{~kg} /$ year with the effort $\left(E_{\mathrm{OAE}}\right)$ of 33,977 trips/ year, The graph of the MSY, MEY, OAE, TR, TC and Profit resultsis presented in Figure 4 below.

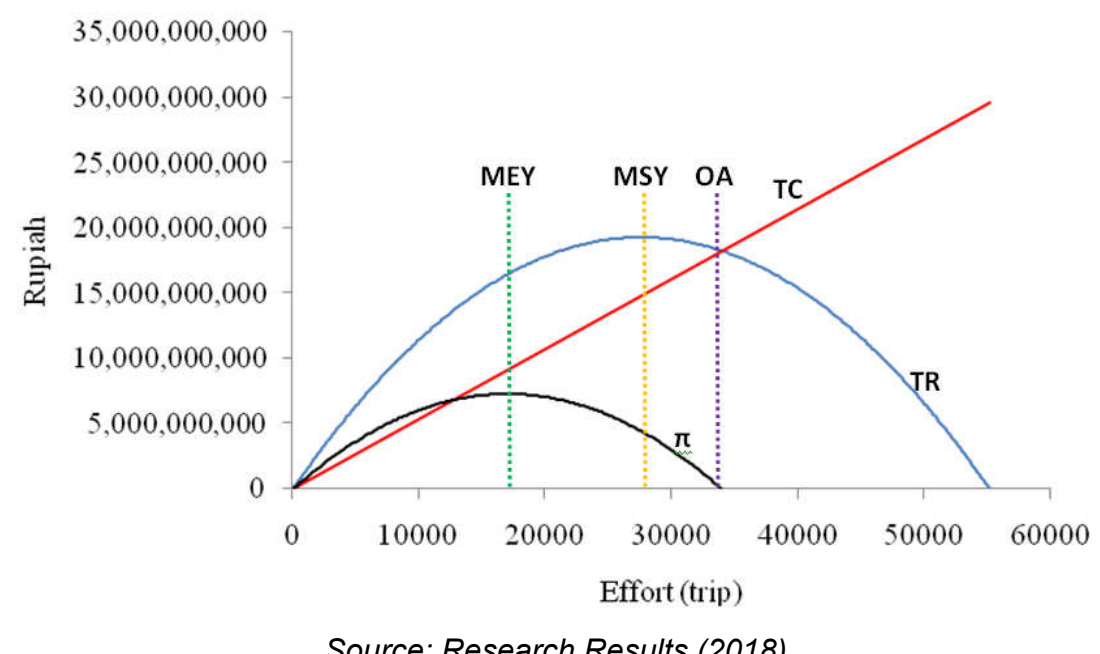

Figure 4 - MSY, MEY, OAE, TR, TC andProfit Curves of Hairtail Fish in Kebumen Regency Waters within the Period of 2008 - 2017

Utilization Rate. The utilization rate of hairtail fish for the last 10 years has very fluctuated. The average value of $\mathrm{TP}_{\mathrm{C}}$ from 2008 to 2017 was $40.51 \%$. The highest $\mathrm{TP}_{\mathrm{C}}$ value occurred in 2012 amounted to $74.85 \%$ while the lowest TP value was $16.53 \%$ in 2010 . The average value of $\mathrm{TP}_{\mathrm{E}}$ was $127.06 \%$. The highest $\mathrm{TP}_{\mathrm{E}}$ valuewas $239.24 \%$ in 2008 while the lowest $\mathrm{TP}_{\mathrm{E}}$ value was $22.98 \%$ in 2009 .

Within the period of $2008-2017$, the utilization rate $\left(T_{C}\right)$ was still below $100 \%$. However, the production can still be improved. In contrast, the average effort rate $\left(\mathrm{TP}_{\mathrm{E}}\right)$ was more than $100 \%$. Until 2011, there had been an attempt to lower the effort rate per year, but the effort went back up to an effort rate of more than $100 \%$ in 2012 . $\mathrm{TP}_{\mathrm{E}}$ values that exceed 
$E_{M S Y}$ can threaten resource sustainability. Reduction of $T P_{E}$ value and increase in fishing gear effectiveness can be one solution that can be done to increase the production of hairtail fish by still concerning on the resource preservation.

Table 6 - Utilization Rate of Hairtail Fish in Kebumen Regency during 2008-2017

\begin{tabular}{l|l|l|l|l|l|l}
\hline Year & Production $(\mathrm{kg})$ & $\mathrm{C}_{\mathrm{MSY}}(\mathrm{kg})$ & $\mathrm{TP}_{\mathrm{C}}(\%)$ & Effort (trip) & $\mathrm{E}_{\mathrm{MSY}}(\operatorname{trip})$ & $\mathrm{TP}_{\mathrm{E}}(\%)$ \\
\hline 2008 & 416,200 & 760,380 & 54.74 & 65,970 & 27,575 & 239.24 \\
2009 & 267,200 & 760,380 & 35.14 & 6,337 & 27,575 & 22.98 \\
2010 & 125,700 & 760,380 & 16.53 & 27,474 & 27,575 & 99.63 \\
2011 & 211,110 & 760,380 & 27.76 & 7,599 & 27,575 & 27.56 \\
2012 & 569,121 & 760,380 & 74.85 & 31,696 & 27,575 & 114.94 \\
2013 & 345,400 & 760,380 & 45.42 & 57,861 & 27,575 & 209.83 \\
2014 & 320,610 & 760,380 & 42.16 & 53,609 & 27,575 & 194.41 \\
2015 & 443,816 & 760,380 & 58.37 & 43,341 & 27,575 & 157.17 \\
2016 & 195,351 & 760,380 & 25.69 & 15,758 & 27,575 & 57.15 \\
2017 & 185,988 & 760,380 & 24.46 & 40,726 & 27,575 & 147.69 \\
Rata-rata & & & 40.51 & & & 127.06 \\
\hline
\end{tabular}

Source: Research Results (2018).

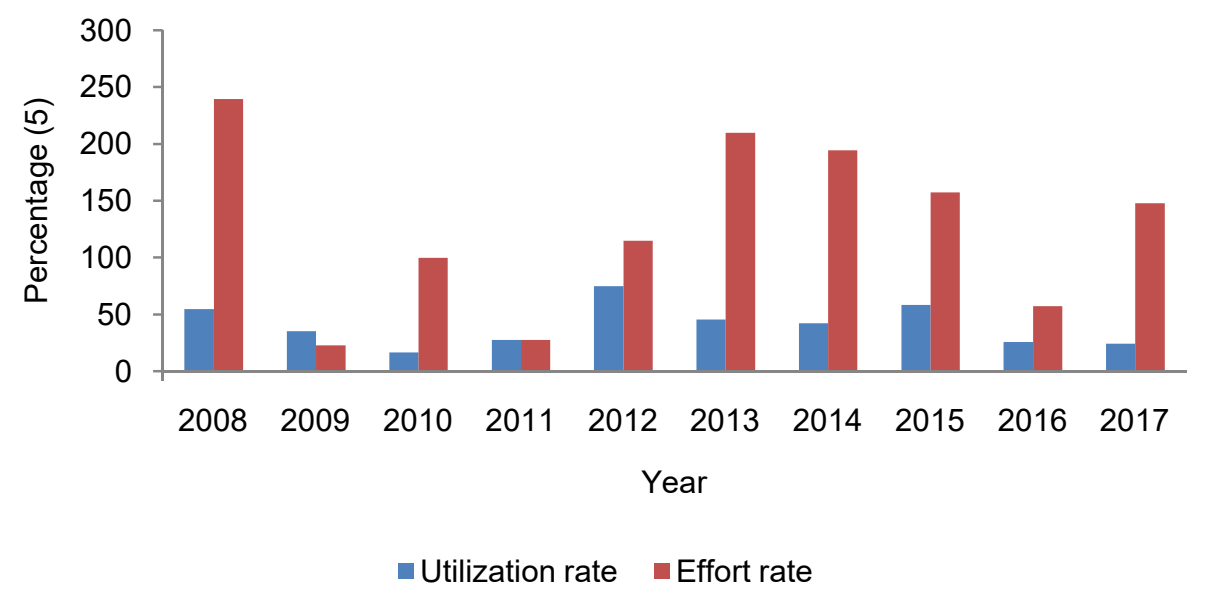

Source: Research Results (2018)

Figure 5 - Utilization Rate of Hairtail Fish in Kebumen Regency Waters Within the Period of $2008-2017$

\section{CONCLUSION AND SUGGESTIONS}

The results of this research have led us to conclude that:

- The $\mathrm{C}_{\mathrm{MSY}}$ value was $760,308 \mathrm{~kg}$ / year and the $\mathrm{E}_{\mathrm{MSY}}$ value was 25,575 trips/ year with the economic profit of IDR 4,482,208,708.00;

- The $C_{M E Y}$ value was $648,311 \mathrm{~kg} /$ year and the $E_{M E Y}$ value was 16,988 trips/ year with the economic profit of IDR 7,327,414,620.00;

- $\quad$ The C $_{\text {OAE }}$ value was $719,388 \mathrm{~kg}$ / year and the $\mathrm{E}_{\mathrm{OAE}}$ value was $33,977 \mathrm{trips} /$ year;

- The average $\mathrm{TP}_{\mathrm{C}}$ value was $40.51 \%$ per year and the $\mathrm{TP}_{\mathrm{E}}$ value was $127.06 \%$ per year. Both of these values indicate that the resource utilization is not effective because the effort rate is more than $100 \%$ yet the production is still far below $100 \%$.

Taken together, the results of this research would seem to suggest that:

- There should be a limitation for the fishing effort rate per year by limiting the number of trips per year;

- There should be development and innovation of hairtail fishing gears so that the fishing effectiveness can increase;

- There should be precise and accurate information about fishing seasons and zones so as to increase the fishing productivity per year. 


\section{REFERENCES}

1. Anonymous. 2016. Market Brief Ikan Konsumsi Di Korea Selatan. Kementerian Perdagangan Republik Indonesia.

2. Suman, A., Wudianto, B. Sumiono, H.E. Irianto, Badrudin, K. Amri. (Ed). 2014. Potensi dan Tingkat Pemanfaatan Sumberdaya Ikan Di Wilayah Pengelolaan Perikanan Republik Indonesia (WPP RI). Badan Penelitian dan Pengembangan Kelautan dan Perikanan. Ref Graphika, Jakarta, $224 \mathrm{hlm}$.

3. Nazir, M. 2005. Metode Penelitian. Ghalia Indonesia, Jakarta.

4. Noija, N., S. Martasuganda, B. Murdiyanto, A.A. Taurusman. 2014. Potensi dan Tingkat Pemanfaatan Sumberday Ikan Demersal di Perairan Pulau Ambon - Provinsi Maluku. Jurnal Teknologi Kelautan dan Perikanan 1 (5): 55 - 64.

5. Patria, A.D., L. Adrianto, T. Kusumastanto, M.M. Kamal., R. Dahuri. 2014. Status Pemanfaatan Sumberdaya Udang Oleh Perikanan Skala Kecil Di Wilayah Peisisr Kabupaten Cilacap. Jurnal Marine Fisheries, 1 (5): 49 - 55.

6. Sparre, P \& S.C. Vennema. 1999. Introduction to tropical fish stock assessment. Part 1. FAO fisheries technical paper no: 306/1 Rev 2.

7. Utami, D.P., I. Gumilar, Sriati. 2012. Analisa Bioekonomi Penangkapan Ikan Layur (Trichiurus sp) Di Perairan Parigi Kabupaten Ciamis. Jurnal Perikanan dan Kelautan 3 (3): $137-144$.

8. Rahmawati, M., A.D. Purnama-Fitri, \& D. Wijayanto. 2013. Analisis Hasil Tangkapan Per Upaya Penangkapan dan Pola Musim Penangkapan Ikan Teri (Stolephorus spp) di Perairan Pemalang. Journal of Fisheries Resources Utilization Management and Technology, 2 (3): 213-222.

9. Widodo, J, \& Suadi. 2006. Pengelolaan Sumberdaya Perikanan Laut. Gajah Mada University Press, Yogyakarta, $250 \mathrm{hlm}$.

10. Wijayanto, D. 2008. Buku Ajar Bioekonomi Perikanan. FPIK. UNDIP. Semarang. 165 hlm. 